\title{
Carbon and nutrient balances in three mountain oases in Northern Oman
}

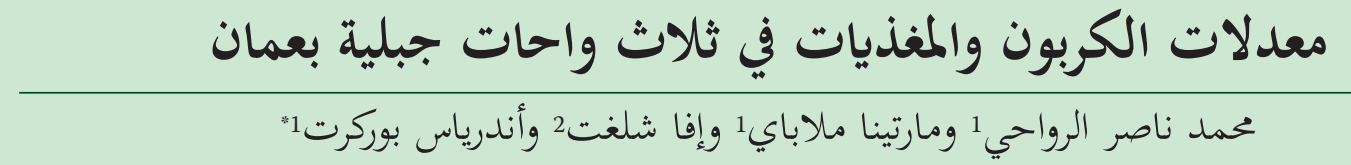

Abstract. Carbon $(\mathrm{C})$ and nitrogen $(\mathrm{N})$ fluxes of two cropping systems in three mountain oases of Al Jabal Al-Akhdar mountains of northern Oman were determined in 2008/09 and 2009/10. These comprised garlic at Ash Sharayjah (1,900 $\mathrm{m}$ asl) and Masayrat (1,030 m asl), pomegranate in Ash Sharayjah and Qasha' (1,640 $\mathrm{m}$ asl), and date palm groves at Masayrat. Goat manure was applied to garlic fields at 47 and 40 t dry matter (DM) ha ${ }^{-1}$ at Ash Sharayjah and 42 and $37 \mathrm{t} \mathrm{DM} \mathrm{ha}^{-1}$ at Masayrat. Pomegranates at Ash Sharayjah and Qasha' received cattle dairy manure at 66 and 60 t DM $\mathrm{ha}^{-1} \mathrm{yr}^{-1}$. Annual total gaseous $\mathrm{C}$ losses varied from 20.9 to $61.2 \mathrm{t} \mathrm{C} \mathrm{ha}^{-1}$ to which $\mathrm{CH}_{4}-\mathrm{C}$ contributed $<2 \%$. Total annual $\mathrm{C}$ surpluses were $12.5 \mathrm{t} \mathrm{ha}^{-1}$ in garlic fields at Ash Sharayjah, while C deficits of $-5.5 \mathrm{t} \mathrm{ha}^{-1}$ were obtained at Masayrat. Annual C surpluses in pomegranate and date palm were 16.7, 7.5, and $1.7 \mathrm{t} \mathrm{ha}^{-1}$ in Ash Sharayjah, Qasha', and Masayrat. Date palm groves had total annual $\mathrm{N}$ surpluses of $1857 \mathrm{~kg} \mathrm{~N} \mathrm{ha}^{-1}$ while pomegranate fields at Ash Sharayjah and Qasha' had annual surpluses of 1414 and $1500 \mathrm{~kg} \mathrm{~N} \mathrm{ha}^{-1}$.

KEYwORDS: Al Jabal Al Akhdar; gaseous emission; leaching; nutrient use efficiency; soil organic matter.

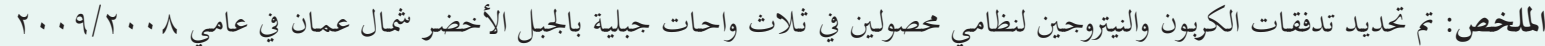

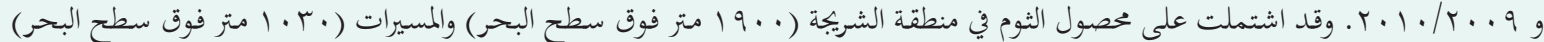

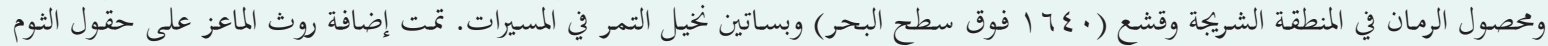

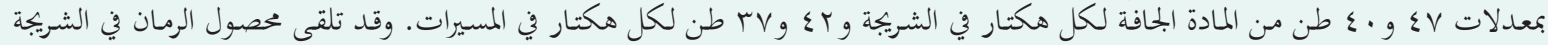

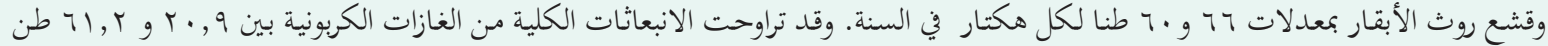

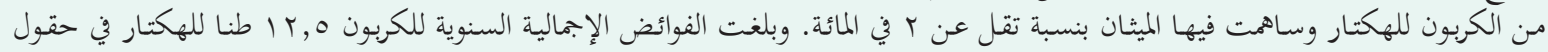

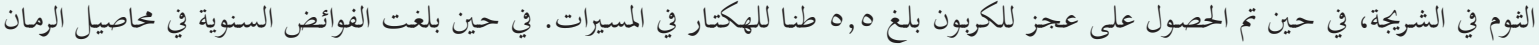

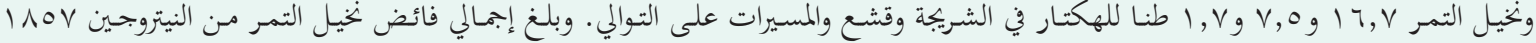

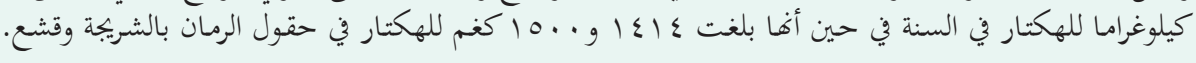

$$
\begin{aligned}
& \text { الكلمات المفتاحية: الجبل الأخضر، الانبعاثات الغازية؛ الرشح، كفاءة استخدام المغذيات، المواد العضوية. }
\end{aligned}
$$

\section{Introduction}

$\mathrm{L}$ ocated at the eastern tip of the Arabian Peninsula, the Sultanate of Oman is characterized by a hyperarid, subtropical climate with an annual precipitation of 0 to $240 \mathrm{~mm}$ compared to a potential evapotranspiration of $>2000 \mathrm{~mm}$ (Nagieb et al. 2004). Under such harsh arid conditions, where water is the most limiting factor for plant production, the millennia-old mountain oases systems in northern Oman have recently received considerable attention of scientists interested in the causes of the apparent sustainability of these agroecosystems (Wichern et al. 2004; Buerkert et al. 2005; Golombek et al. 2007; Siebert et al. 2007). One determinant of the bio-physical sustainability of Omani

\footnotetext{
"1 Andreas Buerkert. ( $\longrightarrow$ ) Organic Plant Production \& Agroecosystems Research in the Tropics \& Subtropics (OPATS), University of Kassel, Steinstr. 19, 37213 Witzenhausen, Germany. Email: tropcrops@ uni-kassel.de

${ }^{2}$ Animal Husbandry in the Tropics and Subtropics, University of Kassel and Gorg-August-Universität Göttingen, Steinstr. 19, 37213 Witzenhausen, Germany.
}

irrigated oasis agriculture is the turnover of carbon $(\mathrm{C})$ and plant nutrients (N, P, and $\mathrm{K})$ for which solid field data from irrigated subtropical conditions are scarce. The existing studies reported high application rates of organic fertilizer to the man-made terrace soils leading to the apparent accumulation of organic $\mathrm{C}$ despite very high emanation of gaseous $\mathrm{C}$ and $\mathrm{N}$ (Wichern et al. 2004; Buerkert et al. 2010). Soil organic mater (SOM) not only supplies energy and nutrients for macro-microorganisms and plants, it also contributes to soil textural stability and water holding capacity (Nyberg et al. 2006) thereby also governing drainage, a key component in irrigated agricultural systems (Luedeling et al. 2005). The turnover of SOM is heavily controlled by the characteristics of organic matter $(\mathrm{C} / \mathrm{N}$ ratio and the concentration of lignin and secondary metabolites such as tannins), soil properties $(\mathrm{pH}$, clay content, redox potential), macro and microorganism communities, crop management practices, and by environmental factors (Kladivko et al. 1987; Deng and Tabatabai 2000; De Neve and Hofman 2002; Agehara and Warncke 2005; Burgos et al. 2006). Microbial activities are known to be altered by the water 


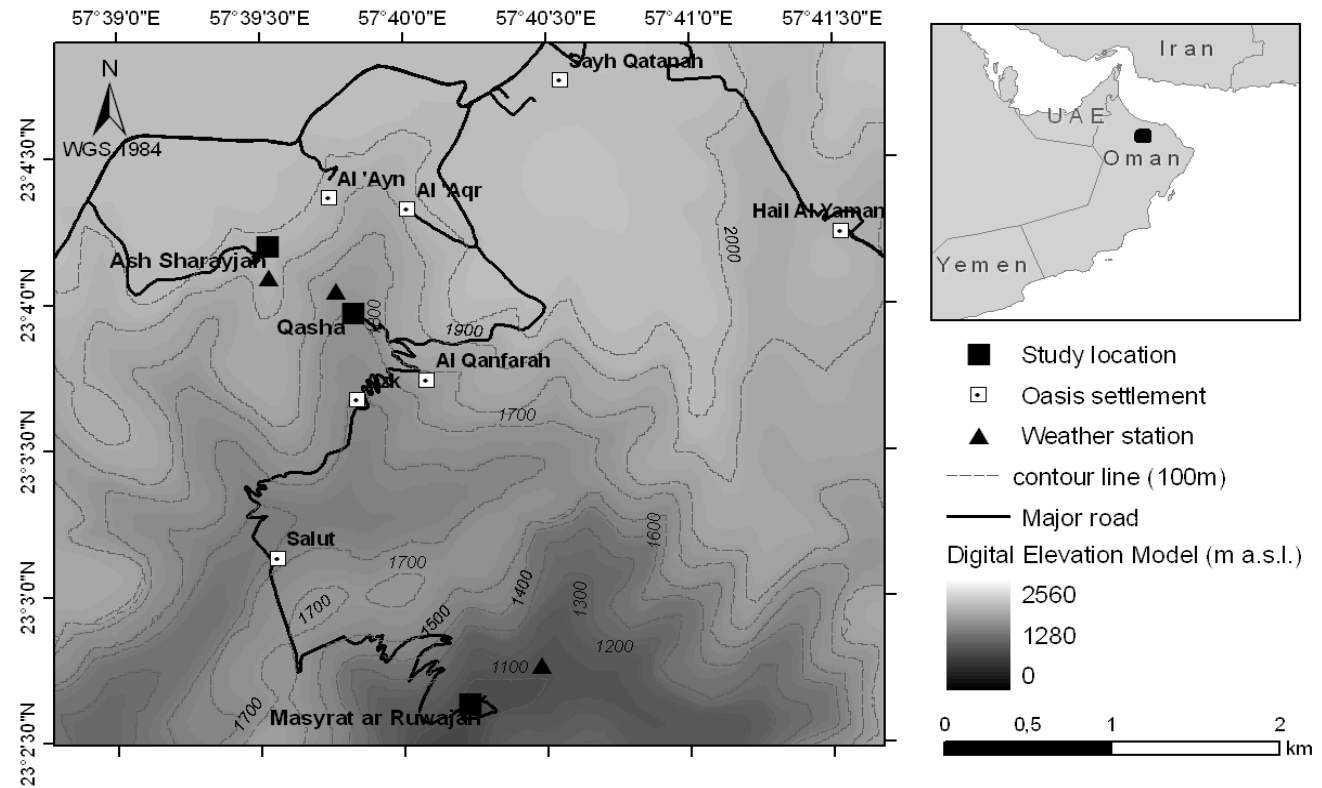

Figure 1. Relief map based on a $100 \mathrm{~m}$ digital elevation model of $\mathrm{Al} \mathrm{Jabal} \mathrm{Al} \mathrm{Akhdar} \mathrm{Mountain} \mathrm{in} \mathrm{northern} \mathrm{Oman} \mathrm{showing}$ the location of the three study oases of Ash Sharayjah, Qasha', and Masayrat ar Ruwajah. Map previously published in Die Erde 145(4): 162-174.

status in the soil leading to aerobic or anaerobic conditions, so that mineralization takes different pathways (Franzluebbers 1999; Cannovo et al. 2004). Similarly, the presence of plants stimulates soil $\mathrm{C}$ and nutrient mineralization through root exudation (Paré et al. 2000; Zaman and Chang 2004).

In this study, we used a soil system balance approach (Mikkelsen 2005) by (i) measuring horizontal inputs and outputs of C, N, P, and $\mathrm{K}$, and (ii) quantifying fluxes of gaseous $\mathrm{C}$ and $\mathrm{N}$ emissions and leaching of mineral $\mathrm{N}$ and $\mathrm{P}$ on representative terraced fields in three oases of different altitudes in $\mathrm{Al}$ Jabal $\mathrm{Al}$ Akhdar Mountains of northern Oman. We hypothesized that $\mathrm{C}$ and nutrient turnover are faster in low altitude oases because of their higher ambient temperature and more frequent irrigation-dependent wet-dry cycles.

Table 1. Soil chemical properties $(0-0.15 \mathrm{~m})$ of the selected fields $(n=6)$ before and after cropping cycles at the oases of Ash Sharayjah, Masayrat ar Ruwajah and Qasha', northen Oman (2008-2009).

\begin{tabular}{|c|c|c|c|c|c|c|c|c|c|c|}
\hline Oases & Crop & Year & $\begin{array}{c}\text { Cropping } \\
\text { Cycle }\end{array}$ & $\mathrm{C}_{\text {org }} \%$ & N\% & $\begin{array}{c}\mathrm{P}(\text { Olsen }) \\
\mathrm{P}_{2} \mathrm{O}_{5} \\
\mathrm{~g} / 100 \mathrm{~g}\end{array}$ & $\begin{array}{c}\mathrm{K} \\
\mathrm{mg} / \mathrm{g}\end{array}$ & $\begin{array}{c}\mathrm{EC} \\
\mathrm{dS} / \mathrm{m}\end{array}$ & $\mathrm{pH}$ & $\mathrm{CaCo}_{3}$ \\
\hline \multirow{3}{*}{ Ash Sharayjah } & \multirow[t]{2}{*}{ Garlic } & 2009 & $\begin{array}{l}\text { Beginning } \\
\text { End }\end{array}$ & $\begin{array}{l}2.76 \\
3.10\end{array}$ & $\begin{array}{l}0.25 \\
0.34\end{array}$ & $\begin{array}{l}0.016 \\
0.022\end{array}$ & $\begin{array}{l}0.14 \\
0.40\end{array}$ & 0.20 & 8.17 & 45.4 \\
\hline & & 2010 & $\begin{array}{l}\text { Beginning } \\
\text { End }\end{array}$ & $\begin{array}{l}3.68 \\
4.13\end{array}$ & $\begin{array}{l}0.31 \\
0.37\end{array}$ & $\begin{array}{l}0.025 \\
0.027\end{array}$ & $\begin{array}{l}0.20 \\
0.24\end{array}$ & 0.17 & 8.37 & 44.3 \\
\hline & Pomegranate & 2009 & $\begin{array}{l}\text { Beginning } \\
\text { End }\end{array}$ & $\begin{array}{l}3.72 \\
4.19\end{array}$ & $\begin{array}{l}0.38 \\
0.42\end{array}$ & $\begin{array}{l}0.031 \\
0.040\end{array}$ & $\begin{array}{l}0.31 \\
0.33\end{array}$ & 0.25 & 8.10 & 44.7 \\
\hline \multirow{3}{*}{ Masayrat } & \multirow{2}{*}{ Garlic } & 2009 & $\begin{array}{l}\text { Beginning } \\
\text { End }\end{array}$ & $\begin{array}{l}5.95 \\
6.19\end{array}$ & $\begin{array}{l}0.39 \\
0.43\end{array}$ & $\begin{array}{l}0.024 \\
0.016\end{array}$ & $\begin{array}{l}0.14 \\
0.12\end{array}$ & 0.24 & 7.97 & 38.9 \\
\hline & & 2010 & $\begin{array}{l}\text { Beginning } \\
\text { End }\end{array}$ & $\begin{array}{l}5.34 \\
6.87\end{array}$ & $\begin{array}{l}0.33 \\
0.50\end{array}$ & $\begin{array}{l}0.013 \\
0.019\end{array}$ & $\begin{array}{l}0.14 \\
0.14\end{array}$ & 0.15 & 8.10 & 37.2 \\
\hline & Date palm & 2009 & $\begin{array}{l}\text { Beginning } \\
\text { End }\end{array}$ & $\begin{array}{l}6.93 \\
5.57\end{array}$ & $\begin{array}{l}0.31 \\
0.46\end{array}$ & $\begin{array}{l}0.006 \\
0.010\end{array}$ & $\begin{array}{l}0.11 \\
0.14\end{array}$ & 0.20 & 7.87 & 40.0 \\
\hline Qasha' & Pomegranate & 2009 & $\begin{array}{l}\text { Beginning } \\
\text { End }\end{array}$ & $\begin{array}{l}2.41 \\
2.87\end{array}$ & $\begin{array}{l}0.30 \\
0.35\end{array}$ & $\begin{array}{l}0.014 \\
0.022\end{array}$ & $\begin{array}{l}0.16 \\
0.17\end{array}$ & 0.16 & 8.26 & 36.6 \\
\hline
\end{tabular}




\section{Materials and methods}

\section{Study area}

The study was carried out in the mountain oases of Ash Sharayjah (57³9’30”E, 2304'10”N, $1900 \mathrm{~m}$ asl) located on the top of the Wadi Muaydin watershed, adjoining the edge of the Sayq plateau in the northern Hajar mountains of Oman (Fig. 1). Just below this oasis is the village of Qasha' (57 $39^{\prime} 50^{\prime \prime} \mathrm{E}, 23^{\circ} 04^{\prime} 00^{\prime} \mathrm{N}, 1640 \mathrm{~m}$ asl), while the lowest oasis of the watershed is Masayrat ar Ruwajah (57 $40^{\prime} 13^{\prime \prime} \mathrm{E}, 23^{\circ} 02^{\prime} 37^{\prime \prime} \mathrm{N}, 1030 \mathrm{~m}$ asl). The terraced agricultural area of Ash Sharayjah amounts to 14.4 ha and farmers irrigate their terraces with water from two springs that emerge near the neighboring oasis of Al'Ayn which was not included in this study. Qasha' contains 2.6 ha of terraced fields and obtains its water also from one of the springs of Al'Ayn, from where the water flows through a steep channel down to the oasis. In Ash Sharayjah and Qasha' crops are dominated by temperate species such as alfalfa (Medicago sativa L.), garlic, oat (Avena sativa L.), onion (Allium cepa L.), wheat (Triticum spp.) pomegranate, peach (Prunus persica L.), and rose (Rosa damascena L.) for rose water production. Agriculture in Masayrat (3.3 ha), in turn, is dominated by the annuals alfalfa (Medicago sativa L.), maize (Zea mays L.), sorghum (Sorghum bicolor L. Moench) and barley (Hordeum vulgare L.), and the typical subtropical perennials date palm and lime (Citrus aurantiifolia L. Swingle). The three oases were selected due to their representative character reflecting altitudinal differences in the typical oasis agriculture of this hyperarid region (Al-Rawahi et al. 2014a).

At each oasis, six representative fields were monitored during two growing seasons (2008/09-2009/10) for annual crops, and during one year for perennial crops in order to investigate fluxes of $\mathrm{C}$ and nutrients in typical oasis cropping systems. To this end garlic and pomegranate were selected in Ash Sharayjah, pomegranate in Qasha, and garlic and date palm in Masayrat.

\section{Soil properties and climatic conditions}

In each field three subsamples of the topsoil (0-0.15 $\mathrm{m}$ ) were collected randomly, air dried, sieved to $<2$ $\mathrm{mm}$, and pooled before and after each cropping cycle or once per year in the case of perennials. Prior to determining particle size distribution in the soil using the sieve-pipette method (Gee and Bauder, 1986), organic matter and calcium carbonate $\left(\mathrm{CaCO}_{3}\right)$ were destroyed by addition of hydrogen peroxide $\left(\mathrm{H}_{2} \mathrm{O}_{2}\right)$ and hydrochloric acid $(\mathrm{HCl})$, respectively. Soil $\mathrm{pH}$ was measured in a 1:2.5 distilled water solution, whereas soil salinity was determined as electrical conductivity (EC) in a 1:10 water solution using a digital conductivity meter (GMH 3410, GHM-Greisinger, Regenstauf, Germany). Soil total $\mathrm{C}$ and $\mathrm{N}$ were measured by a thermal conductivity detector (Vario MAX CHN Analyser, Elementar Analysensysteme $\mathrm{GmbH}$, Hanau, Germany). The percentage of $\mathrm{CaCO}_{3}$ in soil was calculated using the volumetric calcimeter method (Williams, 1948). Soil P was extracted with sodium bicarbonate $\left(\mathrm{NaHCO}_{3}\right)$ according to Watanabe and Olsen (1965) and measured by spectrophotometry (U-2000, Hitachi Ltd, Tokyo, Japan). For soil $\mathrm{K}$ analyses, samples were extracted with calcium acetate lactate and measured with a flame photometer (743 AutoCal, Instrumentation Laboratory Co, Lexington, MA, USA).

To estimate micro-climate differences of the three oases reflecting the effect of the different elevations, air temperature and relative humidity were recorded at 30 min intervals throughout the research period using Hobo-Pro ${ }^{\circ}$ climate loggers (Onset, Bourne, MA, USA). In addition to these devices full Watchdog ${ }^{\oplus}$ weather stations (Spectrum Technologies Inc., Plainfield, IL, USA) were placed at Ash Sharayjah and Masayrat.

\section{Sampling and analysis}

During harvest, garlic plant samples were collected from three $1 \mathrm{~m}^{2}$ subsamples in each of the six fields at each location, weighted to obtain total fresh matter, sundried to constant weight for DM determination, and subsequently ground to $<2 \mathrm{~mm}$ for $\mathrm{C}$ and nutrient anal-

Table 2. Total amounts of goat and cattle dairy manures and concentrations of nitrogen (N), phosphorus (P), potassium (K), and carbon $(C)$ in that have been applied by farmers at the oases of Ash Sharayjah, Qasha', and Masayrat ar Ruwajah, Al Jabal Al Akhdar (northern Oman) during the experimental period (2008-2009).

\begin{tabular}{|c|c|c|c|c|c|c|c|c|}
\hline Crop & Oases & Type & Year & $\begin{array}{l}\text { Total application } \\
\text { T(DM)ha }\end{array}$ & $\mathbf{N}$ & $\begin{array}{c}\mathrm{P} \\
\mathrm{mg} \mathrm{g}^{-1}\end{array}$ & $\mathbf{K}$ & $\begin{array}{l}\mathrm{C} \\
\%\end{array}$ \\
\hline Garlic & Sharayjah & goat & $\begin{array}{l}2008 / 09 \\
2009 / 10\end{array}$ & $\begin{array}{l}47 \\
40\end{array}$ & $\begin{array}{l}22.5 \\
24.0\end{array}$ & $\begin{array}{l}3.0 \\
4.4\end{array}$ & $\begin{array}{l}13.6 \\
13.5\end{array}$ & $\begin{array}{l}46.42 \\
42.82\end{array}$ \\
\hline Garlic & Masayrat & goat & $\begin{array}{l}2008 / 09 \\
2009 / 10\end{array}$ & $\begin{array}{l}42 \\
37\end{array}$ & $\begin{array}{l}25.2 \\
22.3\end{array}$ & $\begin{array}{l}3.3 \\
4.5\end{array}$ & $\begin{array}{l}10.2 \\
14.3\end{array}$ & $\begin{array}{l}50.20 \\
36.32\end{array}$ \\
\hline Pomegranate & Sharayjah & cattle & 2009 & 66 & 25.3 & 3.8 & 31.4 & 37.25 \\
\hline Pomegranate & Qasha' & cattle & 2009 & 60 & 25.2 & 7.1 & 26.2 & 28.53 \\
\hline Date Palm & Masayrat & goat & 2009 & 78 & 25.2 & 3.3 & 13.2 & 47.20 \\
\hline
\end{tabular}


ysis. For pomegranate and date palms fruit yields were quantified for each tree. To this end the total number of pomegranate fruits was counted and classified into three categories: small, medium, and big. Subsequently, average weight, volume, and nutrient concentrations were determined from representative samples to compute fruit yield per tree and surface area occupied. Plant and manure samples were oven-dried at $60^{\circ} \mathrm{C}$, ground $(<2 \mathrm{~mm})$, and analysed for $\mathrm{C}, \mathrm{N}, \mathrm{P}$, and $\mathrm{K}$ as described above for the soil samples. For samples of irrigation water, of which frequency and amounts were determined regularly, dissolved organic carbon (DOC) and total $\mathrm{N}$ were measured using a Dimatec $100^{\circ} \mathrm{CHN}$-Analyzer (Dimatec Analysentechnik GmbH, Essen, Germany).

\section{Horizontal $\mathrm{C}$ and nutrient fluxes}

Horizontal balances were determined by calculating the differences between the total amounts of $\mathrm{C}, \mathrm{N}, \mathrm{P}$, and $\mathrm{K}$ in all inputs such as manures, mineral fertilizers (if applicable), planted garlic cloves, irrigation water, and rainfall and outputs such as crop removals at harvest including understory maize (wherever present in planted perennials) and fruit yields of pomegranate and date palm. In order to account for the contribution of roots to $\mathrm{C}$ balances, total amount of photosynthetic $C$ was estimated for garlic and understory maize by multiplying total harvested DM by a factor of 1.4 based on the assumption that $30 \%$ of the total assimilated $\mathrm{C}$ was allocated to root DM and exudation (Kuzyakov and Domanski 2000).

\section{Apparent nutrient use efficiency (NUE)}

Horizontal nutrient fluxes were used to calculate NUE for the different cropping systems: ( $\sum$ nutrient output with harvest products $/ \sum$ nutrient inputs) (Hedlund et al. 2003). For perennial trees, understory maize was in-

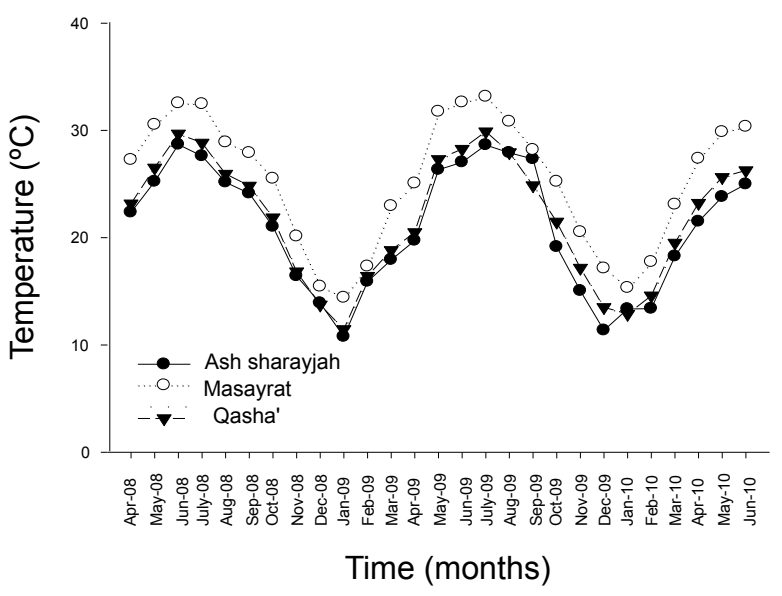

Figure 2. Mean monthly air temperatures recorded at the oases of Ash Sharayjah, Qasha', and Masayrat ar Ruwajah in northern Oman during the research period. Modified after data published in Die Erde 145(4):162-174. cluded in output calculations wherever present.

\section{Vertical carbon and nutrient fluxes}

\section{Collection and analysis of leachates}

Cumulative leaching losses of mineral $\mathrm{N}$ and $\mathrm{P}$ were quantified with mixed-bed ion-exchange resin cartridges (Bischoff 2007; Lang and Kaupenjohann 2004; Predotova et al. 2011). To this end PVC-cartridges were filled with a 2:3 mixture of anion-cation exchange resins and pure silica sand of 120-700 $\mu \mathrm{m}$ (Majan Glass Co., Sohar, Oman; Siegfried et al., 2011). For each cropping system, seven cartridges were buried in each of the selected fields below the rooting zone at $0.50 \mathrm{~m}$ depth and removed after each crop harvest or annually for pomegranate and date palm. After removal from the soil, the resin-sand mixture was separated horizontally into five layers to be able to determine a concentration gradient within each cartridge. From each layer, a subsample of $30 \mathrm{~g}$ was extracted eight times with $100 \mathrm{ml}$ of $0.5 \mathrm{M}$ $\mathrm{NaCl}$ by shaking for one hour followed by filtration into a plastic vial. Subsequently, samples were analyzed for their concentration of leached nutrients with an ICPAES (Spectroflame, Spectro GmbH, Kleve, Germany).

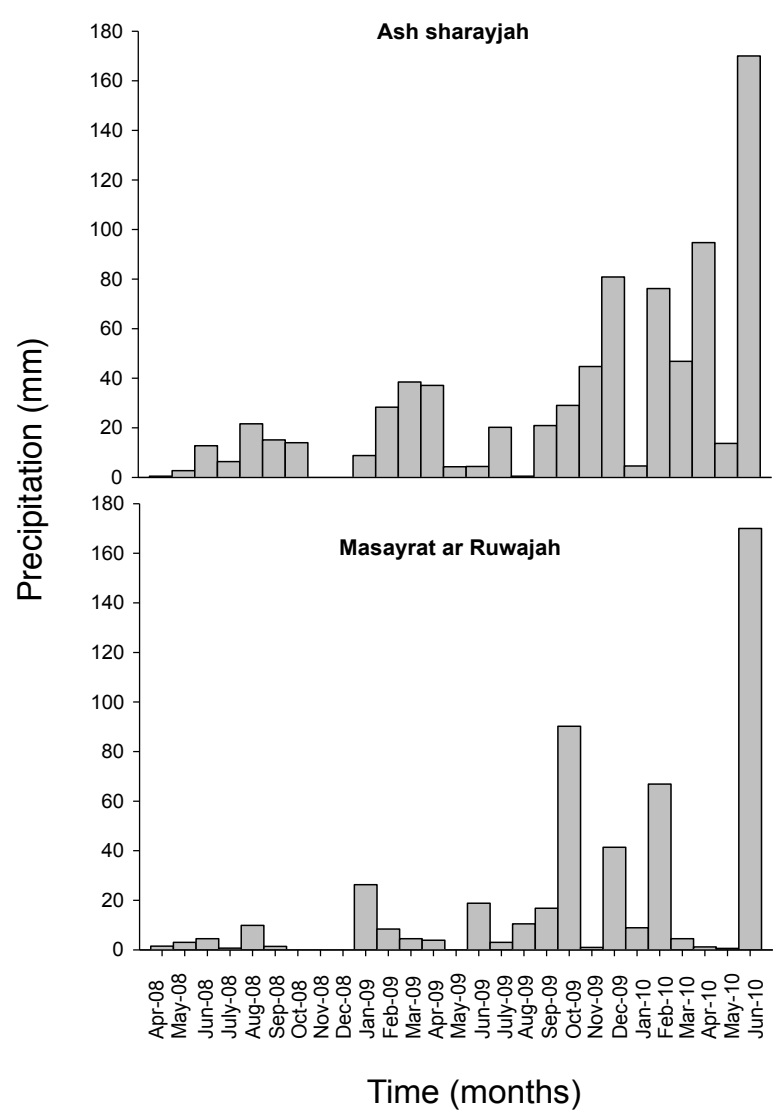

Figure 3. Average monthly precipitation $(\mathrm{mm})$ recorded at the oases of Ash Sharayjah and Masayrat ar Ruwajah, Al Jabal Al Akhdar (Oman) from April 2008 to June 2010. 
Calculations of annual cumulative leaching losses of $\mathrm{N}$ and $\mathrm{P}$ were made following the approach described by Siegfried et al. (2011).

\section{Monitoring of gaseous $\mathrm{C}$ and $\mathrm{N}$ emissions}

On the same fields where leaching cartridges were installed, gaseous emissions of $\mathrm{CO}_{2}-\mathrm{C}, \mathrm{CH}_{4}-\mathrm{C}, \mathrm{NH}_{3}-\mathrm{N}$ and

Table 3. Annual horizontal inputs, outputs and partial balances of carbon $(\mathrm{C})$, nitrogen $(\mathrm{N})$, phosphorus $(\mathrm{P})$, and potassium $(\mathrm{K})$ for garlic, pomegranate, and date palm fields $(\mathrm{n}=6)$ at the oases of Ash Sharayjah, Qasha', and Masayrat ar Ruwajah in northern Oman (2008-2009). Partial balances values with different superscript letters were significantly different $(\mathrm{P}<0.05, \mathrm{LSD})$.

\begin{tabular}{|c|c|c|c|c|c|c|}
\hline \multirow{2}{*}{ Crop } & \multirow{2}{*}{ Oases } & \multirow{2}{*}{ Source } & \multicolumn{4}{|c|}{ Input and output $\left(\mathrm{kg} \cdot \mathrm{ha}^{-1} \cdot \mathrm{yr}^{-1}\right)$} \\
\hline & & & $\mathrm{C}$ & $\mathbf{N}$ & $\mathbf{P}$ & K \\
\hline \multirow{8}{*}{ Garlic } & \multirow[t]{8}{*}{ Sharayjah } & Manure & 38632 & 2001 & 317.2 & 1170.9 \\
\hline & & Cloves (sowing) & 16 & 1 & 0.2 & 1.5 \\
\hline & & Irrigation water & 41 & 57 & 0.0 & 0.3 \\
\hline & & Rainfall & 162 & 34 & n.a & n.a \\
\hline & & Photosynthetic C & 22771 & & & \\
\hline & & Total & 61620 & 2093 & 317.4 & 1172.7 \\
\hline & & Crop yield & -16265 & -1069 & -191.1 & -1486.2 \\
\hline & & Partial balance & $45355^{\mathrm{a}}$ & $1024^{\mathrm{c}}$ & $126.3^{\mathrm{cd}}$ & $-313.5^{c}$ \\
\hline \multirow{8}{*}{ Garlic } & \multirow[t]{8}{*}{ Masayrat } & Manure & 38132 & 1878 & 306.1 & 955.0 \\
\hline & & Cloves (sowing) & 16 & 1 & 0.2 & 1.4 \\
\hline & & Irrigation water & 121 & 103 & 0.0 & 0.5 \\
\hline & & Rainfall & 113 & 13 & n.a & n.a \\
\hline & & Photosynthetic C & 21963 & & & \\
\hline & & Total & 60345 & 1995 & 306.3 & 956.9 \\
\hline & & Crop yield & -15688 & -1011 & -244.2 & -1427.2 \\
\hline & & Partial balance & $44657^{\mathrm{a}}$ & $984^{\mathrm{C}}$ & $62.1^{\mathrm{d}}$ & $-470.3^{\mathrm{C}}$ \\
\hline \multirow{8}{*}{ Pomegranate } & \multirow[t]{8}{*}{ Sharayjah } & Manure & 24728 & 1682 & 249.7 & 2084.9 \\
\hline & & Irrigation water & 33 & 46 & 0.0 & 0.2 \\
\hline & & Rainfall & 138 & 29 & n.a & n.a \\
\hline & & Photosynthetic C* & 7536 & & & \\
\hline & & Total & 32435 & 1757 & 249.7 & 2085.1 \\
\hline & & Crop yield & -2238 & -39 & -7.8 & -70.8 \\
\hline & & Understory maize & -5383 & -209 & -46.0 & -308.4 \\
\hline & & Partial balance & $24814^{\mathrm{b}}$ & $1509^{\mathrm{b}}$ & $195.9^{\mathrm{bc}}$ & $1705.9^{\mathrm{a}}$ \\
\hline \multirow{7}{*}{ Pomegranate } & \multirow[t]{7}{*}{ Qasha' } & Manure & 17237 & 1524 & 430.7 & 1585.7 \\
\hline & & Irrigation water & 58 & 62 & 0.0 & 0.2 \\
\hline & & Rainfall & 138 & 29 & n.a & n.a \\
\hline & & Photosynthetic C & n.a & & & \\
\hline & & Total & 17433 & 1615 & 430.7 & 1586.0 \\
\hline & & Crop yield & -2728 & -39 & -8.5 & -72.8 \\
\hline & & Partial balance & $14705^{\mathrm{b}}$ & $1576^{\mathrm{b}}$ & $422.2^{\mathrm{a}}$ & $1513.2^{\mathrm{a}}$ \\
\hline \multirow{8}{*}{ Date Palm } & \multirow[t]{8}{*}{ Ma } & Manure & 36452 & 1946 & 256.0 & 1019 \\
\hline & & Irrigation water & 154 & 131 & 0.0 & 0.6 \\
\hline & & Rainfall & 101 & 21 & n.a & n.a \\
\hline & & Photosynthetic C* & 5085 & & & \\
\hline & & Total & 41792 & 2098 & 256.0 & 1019.3 \\
\hline & & Crop yield & -1788 & -16 & -3.0 & -39.6 \\
\hline & & Understory maize & -3632 & -131 & -33.0 & -96.8 \\
\hline & & Partial balance & $36372^{\mathrm{a}}$ & $1951^{\mathrm{a}}$ & $220.0^{b}$ & $882.9^{\mathrm{b}}$ \\
\hline
\end{tabular}

*Photosynthetic $C$ was estimated only for understory maize. 
$\mathrm{N}_{2} \mathrm{O}-\mathrm{N}$ were measured using a photo-acoustic infrared multi-gas analyzer (INNOVA 1312-5, AirTech instruments, Ballerup, Denmark; Predotova et al., 2010, 2011). A cuvette of $0.30 \mathrm{~m}$ diameter and $0.11 \mathrm{~m}$ height made of standard PVC tube was used to tightly cover PVC rings installed in the soil of the experimental field in order to create a closed chamber, while inside temperature and humidity were monitored with an attached thermo-hygrometer sensor (PCE-313 A, Paper-Consult Engineering Group, Meschede, Germany). Measurements were conducted immediately after the first irrigation and repeated for three days during each irrigation cycle in order to estimate emission rates at different soil moisture levels (day of irrigation event, day in the middle of the irrigation cycle, and day before the next irrigation event). For each measurement day, gaseous emissions were quantified from three replicates in all four rings installed in each cropping system (totaling 12 measurements per day). At the same time, volumetric soil water content was determined at $0.05 \mathrm{~m}$ depth with a TDR/ FDR soil moisture meter (Theta Probe Sensor attached to Infield7b instrument, UMS, Munich, Germany). Soil
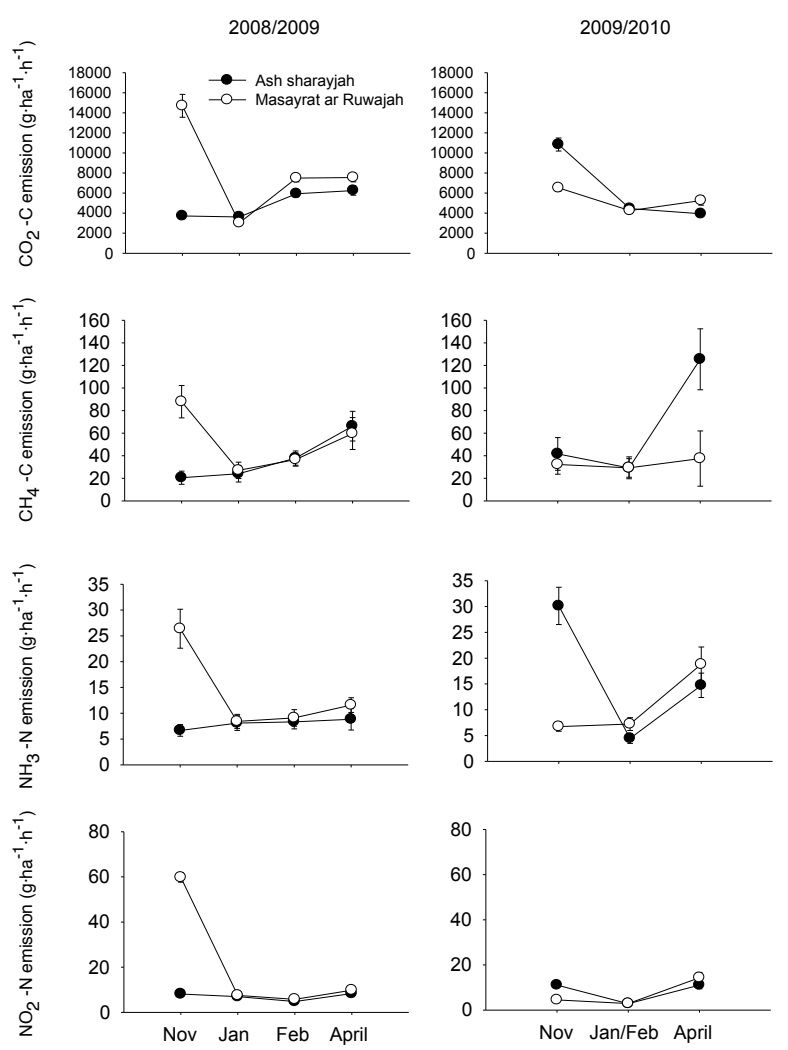

\section{Time (Months)}

Figure 4. Emissions of $\mathrm{CO}_{2}-\mathrm{C}, \mathrm{CH}_{4}-\mathrm{C}, \mathrm{NH}_{3}-\mathrm{N}$, and $\mathrm{N}_{2} \mathrm{O}-\mathrm{N}$, from garlic fields at the oases of Ash Sharayjah and Masayrat ar Rawajah throughout two growing seasons (2008/2009-2009/2010). Vertical bars indicate \pm one standard error of the mean.
Table 4. Annual cumulative leaching losses of mineral nitrogen $(\mathrm{N})$ and phosphorus $(\mathrm{P})$ (mean \pm one standard error) determined by ion exchange resin cartridges from the experimental fields at the oases of Ash Sharayjah, Qasha', and Masayrat ar Ruwajah, Oman (2008-2009).

\begin{tabular}{cccc} 
& & \multicolumn{2}{c}{$\begin{array}{c}\text { Cumulative leaching } \\
\mathrm{g} \mathrm{ha}^{-1} \text { year }^{-1}\end{array}$} \\
Crop & Oases & Mineral (N) & Mineral (P) \\
Garlic & Ash Sharayjah & $452 \pm 26.9$ & $25 \pm 2.8$ \\
Garlic & Masayrat & $613 \pm 65.2$ & $102 \pm 27.1$ \\
Pomegranate & Ash Sharayjah & $232 \pm 31.5$ & $3 \pm 0.5$ \\
Pomegranate & Qasha' & $48 \pm 7.7$ & $7 \pm 0.67$ \\
Date Palm & Masayrat & $73 \pm 13.8$ & $4 \pm 1.5$
\end{tabular}

temperature was recorded with a digital thermometer (Carl Roth GmbH, Karlsruhe, Germany). Emission measurements were conducted in the early afternoon hours (12:00 - 02:00 pm) representing the highest emission rates during the hottest hours in these agroecosystems (Buerkert et al. 2010). For an annual extrapolation of our daily measurements of afternoon gaseous $\mathrm{C}$ and $\mathrm{N}$ losses, the average percentage changes in emissions between minimum and maximum emission rates (morning/midday) measured at the same oases in a previous study were used to estimate daily average emission values (Al-Rawahi et al. 2014b).

\section{Total carbon and nutrient balances}

Total balances of C, N, P, and $\mathrm{K}$ were calculated as the difference between horizontal balances minus vertical fluxes. Since we were unable to obtain complete plant nutrient data for pomegranate and date palm (due to difficulties to account for nutrient storage in woody plant parts and roots, and losses by twigs and leaves), these calculations had only limited value. To partly fill this data gap, we assumed that approximately $39 \%$ of the total annual emitted $\mathrm{C}$ was derived from root respiration and root-derived organic matter microbial respiration (Atarashi-Andoh et al. 2011). Without consideration of $\mathrm{C}$ stored in leaves, stem, and growing roots, this percentage was considered as the photosynthetic $\mathrm{C}$ input allocated to below-ground roots and consequently deducted from the total gaseous $\mathrm{C}$ emitted from both species for total $\mathrm{C}$ balance calculations.

\section{Statistical analysis}

Data were analyzed using SPSS version 17.0 (SPSS Inc., Chicago, USA), while graphs were made with Sigma Plot 10.0 (Systat Software Inc., San Jose, CA, USA). The analysis of variance was followed by LSD post-hoc multiple mean comparisons to test for differences between the two cropping systems (annual versus perennial species). Data of which residuals were not normally distributed were log-transformed before statistical analysis. 


\section{Results}

\section{Soil properties and climatic conditions}

Soils of the man-made irragric Anthrosols on the terraces were similar for all three oases and classified as loamy soils with a particle size distribution of about $15 \%$ clay, $41 \%$ silt, and $44 \%$ sand. High inorganic carbon $\left(\mathrm{C}_{\text {inorg }}\right)$ was determined in all soil samples reflecting a $\mathrm{CaCO}_{3}$ concentration of $44 \%$ at Ash Sharayjah and $40 \%$ at Masayrat. Soil pH averaged 8.2 at Ash Sharayjah, 8.0 at Qasha', and 8.3 at Masayrat. Also, soil organic $\mathrm{C}$ was higher at Masayrat than at Ash Sharayjah and at Qasha' (Table 1). Average ambient air temperature was $21.2^{\circ} \mathrm{C}$ at Ash Sharayjah, $21.6^{\circ} \mathrm{C}$ at Qasha, and $25.4^{\circ} \mathrm{C}$ at Masayrat (Fig. 2).

In 2009, annual precipitation totaled $205 \mathrm{~mm}$ at Ash Sharayjah and 224 at Masayrat, while in 2010 more rainfall events occurred and annual precipitation totaled 639 and $379 \mathrm{~mm}$ at Ash Sharayjah and Masayrat, respectively (Fig. 3). Garlic fields received a total precipitation of $131 \mathrm{~mm}$ at Ash Sharayjah and $43 \mathrm{~mm}$ at Masayrat during the growing season from November 2008 to April 2009. Rainfall was higher during the second season (2009/2010) with cumulative values of $299 \mathrm{~mm}$ at Ash
Sharayjah and $124 \mathrm{~mm}$ at Masayrat.

\section{Horizontal $\mathrm{C}$ and nutrient fluxes}

Manure was the main source of $\mathrm{C}$ and nutrient inputs (Table 3). Although we tried to select fields with similar application rates of manure, application depended on cropping system (annual versus perennial species), availability and frequency of irrigation water, distance and access to the fields, and season (winter versus summer). Manure was surface applied by the farmers 2-3 times during the experimental period on the irrigated garlic fields forming a manure layer of $0.03 \mathrm{~m}$ height. At Ash Sharayjah, garlic fields received goat manure at average rates of 47 and $40 \mathrm{t} \mathrm{DM} \mathrm{ha-1} \mathrm{during} \mathrm{the} \mathrm{growing}$ seasons of the years $2008 / 2009$ and $2009 / 2010$, respectively (Table 2). Similarly, goat manure was applied to garlic fields at Masayrat with an average application rate of 42 and $37 \mathrm{t} \mathrm{DM} \mathrm{ha}^{-1}$ during the 2-years growing seasons. Farmers also applied goat manure to date palms at Masayrat at an average rate of $78 \mathrm{t} \mathrm{DM} \mathrm{ha-1}$. In contrast, pomegranates at Ash Sharayjah and Qasha' received cattle dairy manure at 66 and $60 \mathrm{t}$ dry matter ha-1.

Average annual inputs of $\mathrm{C}$ and $\mathrm{N}$ from manure were $62 \%$ of total C and $95 \%$ of total $\mathrm{N}$ in Ash Sharayjah garlic fields and $63 \%$ of $\mathrm{C}$ and $94 \%$ of $\mathrm{N}$ in Masayrat garlic

Table 5. Estimated annual carbon and nitrogen gaseous losses from selected experimental fields at the oases of Ash Sharayjah, Qasha',and Masayrat, northern Oman (2008-2009). Data represent means \pm one standard error.

\begin{tabular}{|c|c|c|c|c|}
\hline Crop & Oases & Gas & $\begin{array}{c}\text { Afternoon emission } \\
\text { Mean } \pm \text { Std. error } \\
\text { kg.ha }{ }^{-1} \cdot \text { year }^{-1}\end{array}$ & $\begin{array}{c}\text { Estimated } \\
\text { annual losses } \\
\text { ha }^{-1} \cdot \text { year }^{-1}\end{array}$ \\
\hline \multirow{4}{*}{ Garlic } & \multirow{4}{*}{ Sharayjah } & $\mathrm{CO}_{2}-\mathrm{C}$ & $49442 \pm 3036$ & \multirow{3}{*}{$32.8 \mathrm{t} \mathrm{C}$} \\
\hline & & $\mathrm{CH}_{4}-\mathrm{C}$ & $449.1 \pm 108.24$ & \\
\hline & & $\mathrm{NH}_{3}-\mathrm{N}$ & $106.9 \pm 16.66$ & \\
\hline & & $\mathrm{N}_{2} \mathrm{O}-\mathrm{N}$ & $67.3 \pm 8.52$ & $108.6 \mathrm{~kg} \mathrm{~N}$ \\
\hline \multirow{4}{*}{ Garlic } & \multirow{4}{*}{$\mathrm{Ma}$} & $\mathrm{CO}_{2}-\mathrm{C}$ & $59279 \pm 3958$ & \multirow{3}{*}{$50.2 \mathrm{tC}$} \\
\hline & & $\mathrm{CH}_{4}-\mathrm{C}$ & $506.0 \pm 107.95$ & \\
\hline & & $\mathrm{NH}_{3}-\mathrm{N}$ & $108.6 \pm 17.03$ & \\
\hline & & $\mathrm{N}_{2} \mathrm{O}-\mathrm{N}$ & $122.3 \pm 12.12$ & $156.5 \mathrm{~kg} \mathrm{~N}$ \\
\hline \multirow{4}{*}{ Pomegranate } & \multirow{4}{*}{ Sharayjah } & $\mathrm{CO}_{2}-\mathrm{C}$ & $31164 \pm 2381$ & \multirow{3}{*}{$20.9 \mathrm{t} \mathrm{C}$} \\
\hline & & $\mathrm{CH}_{4}-\mathrm{C}$ & $597.2 \pm 112.22$ & \\
\hline & & $\mathrm{NH}_{3}-\mathrm{N}$ & $75.3 \pm 15.42$ & \\
\hline & & $\mathrm{N}_{2} \mathrm{O}-\mathrm{N}$ & $75.7 \pm 16.04$ & $93.4 \mathrm{~kg} \mathrm{~N}$ \\
\hline \multirow{4}{*}{ Pomegranate } & \multirow{4}{*}{ Qasha' } & $\mathrm{CO}_{2}-\mathrm{C}$ & $27756 \pm 2328$ & \multirow{3}{*}{$18.5 \mathrm{t} \mathrm{C}$} \\
\hline & & $\mathrm{CH}_{4}-\mathrm{C}$ & $377.0 \pm 73.79$ & \\
\hline & & $\mathrm{NH}_{3}-\mathrm{N}$ & $73.3 \pm 14.17$ & \\
\hline & & $\mathrm{N}_{2} \mathrm{O}-\mathrm{N}$ & $48.7 \pm 8.91$ & $76.3 \mathrm{~kg} \mathrm{~N}$ \\
\hline \multirow{4}{*}{ Date Palm } & \multirow{4}{*}{ Masayrat } & $\mathrm{CO}_{2}-\mathrm{C}$ & $72420 \pm 4827$ & \multirow{3}{*}{$61.2 \mathrm{tC}$} \\
\hline & & $\mathrm{CH}_{4}-\mathrm{C}$ & $466.5 \pm 81.42$ & \\
\hline & & $\mathrm{NH}_{3}-\mathrm{N}$ & $68.1 \pm 9.86$ & \\
\hline & & $\mathrm{N}_{2} \mathrm{O}-\mathrm{N}$ & $68.5 \pm 7.55$ & $92.7 \mathrm{~kg} \mathrm{~N}$ \\
\hline
\end{tabular}



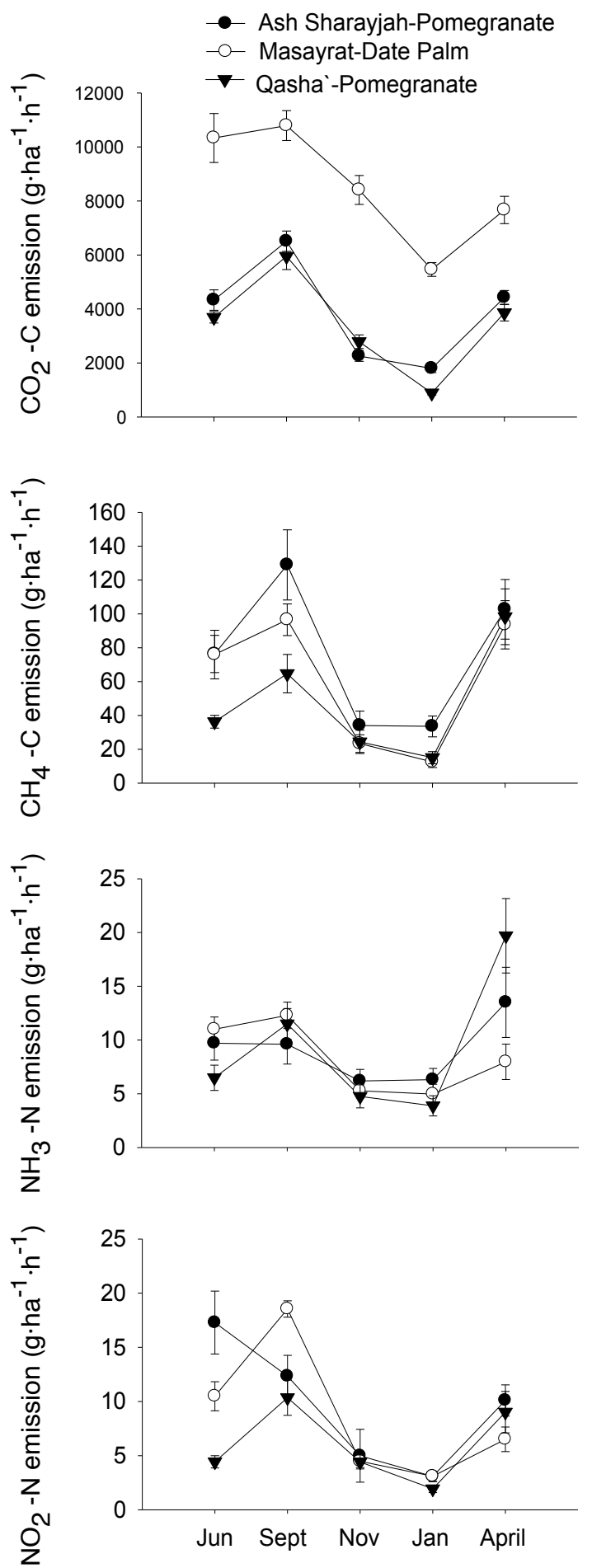

Time (Months)

Figure 5. Emissions of $\mathrm{CO}_{2}-\mathrm{C}, \mathrm{CH}_{4}-\mathrm{C}, \mathrm{NH}_{3}-\mathrm{N}$, and $\mathrm{N}_{2} \mathrm{O}-\mathrm{N}$, from garlic fields at the oases of Ash Sharayjah and Masayrat ar Rawajah throughout two growing seasons (2008/2009-2009/2010). Vertical bars indicate \pm one standard error of the mean.
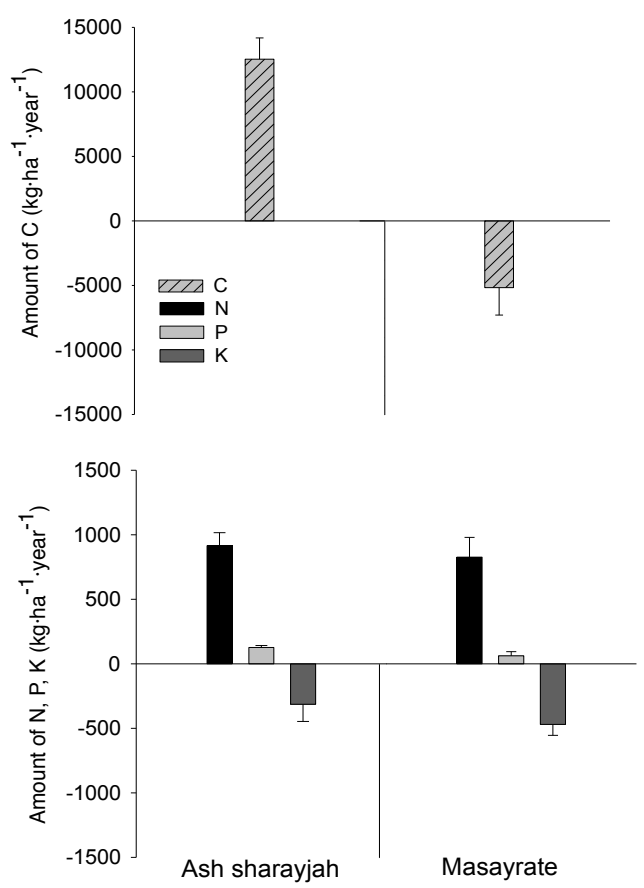

Figure 6. Annual total balances of carbon (C), nitrogen $(\mathrm{N})$, phosphorus $(\mathrm{P})$, and potassium $(\mathrm{K})$ in garlic fields $(\mathrm{n}=$ 6) at the oases of Ash Sharayjah and Masayrat ar Ruwajah in northern Oman. Data represent means of two growing seasons $(2008 / 2009$ - 2009/2010) with vertical bars indicating \pm one standard error.

fields, whereas average annual inputs of photosynthetic $\mathrm{C}$ were 37 and $36 \%$ of total $\mathrm{C}$ in garlic fields at Ash Sharayjah and Masayrat, respectively. Total annual C and nutrient inputs in garlic fields were similar $(\mathrm{P}>0.05)$ in both oases (Table 3). As a result, garlic total DM yield and annual horizontal balances for both oases were not significantly different $(\mathrm{P}>0.05)$.

Although our data showed major differences between annual and perennial cropping systems, partial $\mathrm{C}$ balances of garlic and date palm were not significantly different $(P>0.05)$. Nitrogen surpluses, in contrast, were significantly larger $(\mathrm{P}<0.05)$ in date palm than in all other crops. Phosphorus and $\mathrm{K}$ partial balances of pomegranate at Qasha' and date palm at Masayrat were similar to those of pomegranate at Ash Sharayjah. Although annual horizontal $\mathrm{K}$ balances in garlic fields of both oases were negative, they were positive for pomegranate and date palm. Average annual C, N, P, and K exported with understorey maize were 4.3, 4.9, 3.4 and 1.4-fold higher than in pomegranate yields at Ash Sharayjah and 6.9, 9.9, 1.4 and 1.0-fold higher than in harvested dates. Compared to pomegranate, date palm fields received higher $\mathrm{C}$ and $\mathrm{N}$ inputs and lower $\mathrm{P}$ and $\mathrm{K}$ inputs. Partial balances of $C, N$, and $P$ in date palm therefore were 46, 29 and $12 \%$ higher than balances calculated from pomegranate 


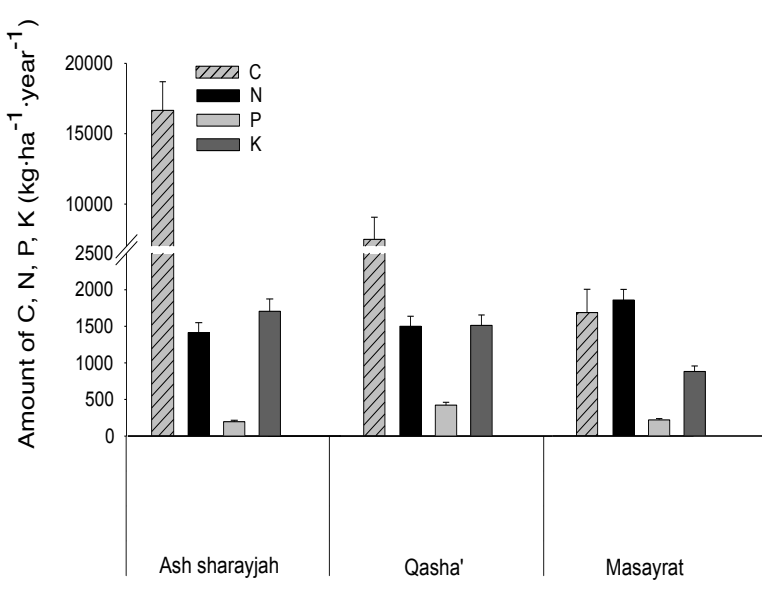

Figure 7. Annual total balances of carbon (C), nitrogen $(\mathrm{N})$, phosphorus $(\mathrm{P})$, and potassium $(\mathrm{K})$ in pomegranate fields $(n=6)$ at oases of Ash Sharayjah and Qasha' and date palm fields at oasis of Masayrat ar Ruwajah in northern Oman during the period of April 2009 to April 2010. Data represent means with vertical bars indicating \pm one standard error.

at Ash Sharayjah, while K balance was $48 \%$ lower.

\section{Apparent nutrient use efficiency NUE}

Annual apparent NUE was highest in garlic with average $\mathrm{N}, \mathrm{P}$, and $\mathrm{K}$ use efficiencies of 51,60 , and $127 \%$ at Ash Sharayjah and 50, 60, and 149\% at Masayrat. Average apparent NUEs of pomegranate at Ash Sharayjah, Qasha, and date palm at Masayrat were 15,3 , and $7 \%$, respectively. In perennial trees, PUE and KUE tended to be higher for pomegranate at Ash Sharayjah (22 and 19\%) compared to date palm at Masayrat (14 and 13\%), while PUE and KUE was with 2 and 5\% smallest in pomegranate at Qasha'.

\section{Cumulative leaching losses}

Most mineral $\mathrm{N}$ was leached as $\mathrm{NO}_{3}-\mathrm{N}$, whereas $\mathrm{NH}_{4}-\mathrm{N}$ was below detection limit for all cartridges. Annual cumulative leaching losses of mineral $\mathrm{N}$ and $\mathrm{P}$ were much higher in garlic fields than in perennial crops (Table 4). Annual mineral $\mathrm{N}$ leaching losses ranged between 0.45-0.61 kg N ha-1 year $^{-1}$ for garlic and 0.23-0.07 kg N $\mathrm{ha}^{-1}$ year $^{-1}$ for perennial trees. Apparent annual mineral $\mathrm{P}$ leaching from perennial trees was below $0.01 \mathrm{~kg} \mathrm{P} \mathrm{ha}^{-1}$ year $^{-1}$.

\section{Gaseous emissions}

Estimated annual gaseous $\mathrm{C}$ and $\mathrm{N}$ losses were higher in garlic than in perennial cropping systems (Table 5) and regardless of the cropping system gaseous $\mathrm{C}$ were higher at Masayrat than at Ash Sharayjah despite the higher application rate of manure at the latter site. Total annual gaseous $\mathrm{N}$ losses from garlic fields were 109 ha $^{-1}$ year $^{-1}$ at Ash Sharayjah and $157 \mathrm{~kg} \mathrm{~N} \mathrm{ha}^{-1}$ year $^{-1}$ at Masayrat, whereas annual gaseous $\mathrm{C}$ losses were $33 \mathrm{t}$ ha $^{-1}$ year $^{-1}$ at Ash Sharayjah and $50 \mathrm{t} \mathrm{C} \mathrm{ha-}^{-1}$ year $^{-1}$ at Masayrat. While $\mathrm{NH}_{3}-\mathrm{N}$ constituted $63 \%$ of total gaseous $\mathrm{N}$ losses in garlic fields at Ash Sharayjah, they were 48\% at Masayrat. Regardless of cropping system and altitude, $\mathrm{NH}_{3}-\mathrm{N}$ and $\mathrm{N}_{2} \mathrm{O}-\mathrm{N}$ fluxes were highest during the first few days after manure application and gradually decreased thereafter (Fig. 4).

For perennials time dependent fluxes of $\mathrm{C}$ and $\mathrm{N}$ were surprisingly similar across the three oases (Fig. 5). In January, flux rates obtained their annual minima. Total estimated gaseous $\mathrm{NH}_{3}-\mathrm{N}$ and $\mathrm{NO}_{2}-\mathrm{N}$ losses were highest in pomegranate at Ash Sharayjah (93 $\mathrm{kg} \mathrm{N} \mathrm{ha}^{-1}$ year $\left.^{-1}\right)$ and at Qasha' (76 kg N ha-1 year $^{-1}$ ) despite the much higher temperature and manure application rate in date palm at Masayrat (93 $\mathrm{kg} \mathrm{N}$ ha $^{-1}$ year $\left.^{-1}\right) \cdot \mathrm{CO}_{2}-\mathrm{C}$ emissions in date palm at Masayrat were about 3-times higher than in pomegranate at Ash Sharayjah and Qasha, reaching a maximum flux rate of $11 \mathrm{~kg} \mathrm{ha}^{-1} \mathrm{~h}^{-1}$ in September (Fig. 5). Consequently, annual gaseous $\mathrm{C}$ losses in perennials were 21, 19, and 61 t C ha-1 year $^{-1}$ at Ash Sharayjah, Qasha', and Masayrat, respectively (Table 5).

\section{Total carbon and nutrient balances}

Total annual $\mathrm{C}$ balances of garlic fields were positive (a surplus of $12.5 \mathrm{t} \mathrm{ha}^{-1}$ ) for Ash Sharayjah and in deficit (-5.5 $\mathrm{t} \mathrm{ha}^{-1}$ ) for Masayrat (Fig. 6), while annual N balances in garlic were with 915 and $826 \mathrm{~kg} \mathrm{ha}^{-1}$ similarly positive at Ash Sharayjah and Masayrat. Annual P surpluses were with $130 \mathrm{~kg} \mathrm{ha}^{-1}$ twice as positive in garlic at Ash Sharayjah than at Masayrat $\left(60 \mathrm{~kg} \mathrm{P} \mathrm{ha}^{-1}\right)$. Garlic annual $\mathrm{K}$ balances, in contrast, were negative in both oases reflecting the high amounts of $\mathrm{K}$ exported with the harvested produce (Table 3 ). Annual $C$ surpluses in pomegranate and date palm were 16.7, 7.5, and $1.7 \mathrm{tha}^{-1}$ at Ash Sharayjah, Qasha, and Masayrat, respectively (Fig. 7). At

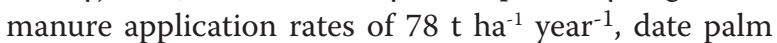
had with $1860 \mathrm{~kg} \mathrm{~N} \mathrm{ha}^{-1}$ the highest total annual $\mathrm{N}$ surplus, while the average annual $\mathrm{K}$ balance was $880 \mathrm{~kg} \mathrm{ha}^{-1}$. Pomegranate at Ash Sharayjah and Qasha' had annual N surpluses of 1410 and $1500 \mathrm{~kg} \mathrm{ha}^{-1}$. Total annual P surpluses in pomegranate at Ash Sharayjah were $196 \mathrm{~kg} \mathrm{ha}^{-1}$ and at Qasha' $420 \mathrm{~kg} \mathrm{ha}^{-1}$, whereas annual $\mathrm{K}$ surpluses amounted to 1710 and $1510 \mathrm{~kg} \mathrm{ha}^{-1}$.

\section{Discussion}

The surprisingly large $\mathrm{N}_{2} \mathrm{O}-\mathrm{N}$ fluxes from garlic fields at Masayrat compared to the prevailing dominance of $\mathrm{NH}_{4}-\mathrm{N}$ in fields at Ash Sharayjah (Table 5) may be caused by the difference in wet-dry cycles at both locations. Over the 180 day growing season there were 15 cycles at the high altitude oasis of Ash Sharayjah compared to 26 cycles at the low altitude oasis of Masayrat. Annual $\mathrm{C}$ losses from date palm at Masayrat were 67\% higher than from pomegranate at Ash Sharayjah and Masayrat which probably reflected the very high annual manure input of $78 \mathrm{t} \mathrm{DM} \mathrm{ha}^{-1}$ to date palm fields as well as the 
much higher air temperature at the low altitude oasis of Masayrat (Fig. 2). In their study of gaseous $\mathrm{N}$ and $\mathrm{C}$ losses from the northern Oman costal plain of Al-Batinah, Siegfried et al. (2011) reported similarly high fluxes that were related to a very fast $\mathrm{C}$ and nutrient turnover. $\mathrm{Al}$ though they used lower manure application rates than in our study, total gaseous $\mathrm{N}$ and $\mathrm{C}$ losses were similar. This it is likely due to the very high temperatures in the Omani lowlands.

Regardless of the cropping system, cumulative annual leaching losses of mineral $\mathrm{N}$ and $\mathrm{P}$ were very low compared to the findings from sandy lowland soils by Siegfried et al. (2011). These low rates may be due to a combination of low seepage, differences in the particle size distribution and the higher organic $\mathrm{C}$ content of our soils. In any case, it should be noted that the resin technique used to measure leachates does not quantify organic N and P. Ouédraogo at al. (2001) have reported that the application of large amounts of organic matter can lead to an increase of soil cation exchange capacity (CEC) in subtropical soils and Jarecki et al. (2008) reported that the higher CEC in clay soils led to a substantial adsorption of $\mathrm{NH}_{4}^{+}$. Also, Szili-Kovács et al. (2007) reported that application of organic substrates may enhance $\mathrm{N}$ immobilization in the microbial biomass As a result of the high nutrient exports in harvested garlic, nutrient surpluses in perennials were much higher, especially for $\mathrm{N}$ and $\mathrm{K}$. Carbon balances, instead, seemed to largely depend on $\mathrm{C}$ inputs from manure and photosynthetic $\mathrm{C}$ rather than on $\mathrm{C}$ exports at harvest. Despite the higher application rates of goat manure to garlic fields, $\mathrm{K}$ inputs to pomegranate were higher given the use of cow manure in this system. Our results indicate that cattle manure had a much higher K concentration than goat manure (Table 1). Although the manure rates in date palm were higher than in garlic, both systems had similar horizontal $\mathrm{C}$ balances, whereby our total annual $\mathrm{C}$ and nutrient exports were much lower than in the more intensively managed palm groves studied by Buerkert et al. (2005). This difference may also be due to a serious infection of the date palms at Musayrat with the dubas bug (Ommatissus binotatus lybicus) during our experimental period leading to unusually low date yields. During their life cycle and development, these insects attract deleterious fungi that feed on honeydew on infected leaves and fruits which causes a reduction of photosynthesis and subsequent growth depression (Klein and Venezian 1985).

Annual apparent NUE was much higher in annual crops than in perennials. Similar to our results, data obtained from 197 countries indicated average use efficiencies of $50 \%$ for N, $40 \%$ for P, and $75 \%$ for K (Sheldrick et al., 2002). The lower NUE of the perennial trees compared to garlic was largely due to much lower nutrient outputs in fruit production. However, calculation of the annual apparent NUE in perennial trees based on harvested yield does not take into account total nutrient uptake and storage by the trees (Hedlund et al., 2003). The high $\mathrm{K}$ uptake by garlic crops raise questions about soil K sources. Further investigations can play an important role in assessing the effect of soil $\mathrm{K}$ depletion on longterm crop production.

The reliability of our total $\mathrm{C}$ balances is severely hampered by the lack of reliable data on root $C$ contributions which has been the subject of much recent research (Kuzyakov et al. 2001; Kuzyakov 2002; Werth and Kuzyakov 2008; Pumpanen et al. 2009). From their comprehensive studies under controlled conditions Kuzyakov and Larionova (2006), concluded that root respiration contributed approximately $40 \%$ to the total $\mathrm{CO}_{2}$ efflux from soils. Kelting et al. (1998) have partitioned soil respiration into: (1) $32 \%$ as a root respiration, (2) $20 \%$ as a microbial respiration in the rhizosphere, and (3) $48 \%$ as root free soil respiration (basal respiration). A recent study (Atarashi-Andoh et al. 2011) on the partitioning soil heterotrophic and autotrophic respiration using ${ }^{14} \mathrm{C}$ concluded that about $31-39 \%$ of the total $\mathrm{CO}_{2}$ efflux from the soil were from root-derived C. Such isotopes studies would be necessary to trace the fate of the assimilated $\mathrm{C}$ by annual and perennial trees in agroecosystems such as of our study.

\section{Conclusion}

The patterns of annual $\mathrm{C}$ and $\mathrm{N}$ emissions reflected the high application rate of manure as well as the variation of air temperature along the altitudinal gradient within the three oases. The removal of $\mathrm{K}$ in harvested garlic greatly exceeded inputs. Our data indicate a very high soil biological activity in all three oases and support previous findings demonstrating the very high $\mathrm{C}$ and $\mathrm{N}$ turnover under irrigated subtropical conditions such as in our study area. To better tailor plant nutrient uptake to release from the large amounts of manure applied, further research is necessary that systematically examines the role of manure quality and incorporation on decomposition.

\section{Acknowledgements}

We thank the farmers of Al Jabal Al Akhdar and the Agricultural Extension Centre of the Ministry of Agriculture and Fisheries at Sayh Qatanah (Oman) who supported this research infrastructurally. We are also thankful to Eva Wiegard and Claudia Thieme for their analytical assisting. This work was funded by the Deutsche Forschungsgemeinschaft (DFG) within the Graduate Research Training Group 1397 'Regulation of Soil Organic Matter and Nutrient Turnover in Organic Agriculture' at University of Kassel-Witzenhausen, Germany. 


\section{References}

Agehara, S., and Warncke, D.D. 2005. Soil moisture and temperature effects on nitrogen release from organic nitrogen sources. Soil Science Society of America Journal 69(6):1844-1855.

Al-Rawahi, M.N., Brinkmann, K., Schlecht, E., and Buerkert, A. 2014. Effects of changing water availability on land-use in irrigated mountain oases of $\mathrm{Al}$ Jabal Al Akhdar, northern Oman. Die Erde 145(4):162-174.

Al-Rawahi, M.N., Melapie, M., and Buerkert, A. 2014. Nitrogen and carbon emissions from $\mathrm{Al}$ Jabal $\mathrm{Al}$ Akhdar oasis systems in northern Oman. Journal of Oman Studies 18:13-24.

Atarashi-Andoh, M., Koarashi, J., Ishizuka, S., and Hirai, K. 2011. Seasonal patterns and control factors of $\mathrm{CO}_{2}$ effluxes from surface litter, soil organic carbon, and root-derived carbon estimated using radiocarbon signatures. Agricultural and Forest Meteorology 153:149-158.

Buerkert, A., Jahn, H., Golombek, S.D., Al-Rawahi, M.N., and Gebauer, J. 2010. Carbon and nitrogen emissions from stored manure and cropped fields in irrigated mountain oases of Oman. Journal of Agriculture and Rural Development in the Tropics and Subtropics 111:65-73.

Buerkert, A., Nagieb, M., Siebert, S., Khan, I., and AlMaskri, A. 2005. Nutrient cycling and field-based partial nutrient balances in two mountain oases of Oman. Field Crops Research 94:149-164.

Burgos, P., Madejón, E., Cabrera, F. 2006. Nitrogen mineralization and nitrate leaching of a sandy soil amended with different organic wastes. Waste Management and Research 24:175-182.

Cannovo, P., Richaume, A., and Lafolie, F. 2004. Fate of nitrogen and carbon in the vadose zone: in situ and laboratory measurements of seasonal variations in aerobic respiratory and denitrifying activities. Soil Biology \& Biochemistry 36:463-478.

Cuttle, S. 2002. Nutrient budgets as a tool for researchers and farmers. UK Organic Research 2002, Aberystwyth, United Kingdom.

De Neve, S., Hofman, G. 2002. Quantifying soil water effects on nitrogen mineralization from soil organic matter and from fresh crop residues. Biology and Fertility of Soils 35(5):379-386.

Deng, S.P., and Tabatabai, M.A. 2000. Effect of cropping systems on nitrogen mineralization in soils. Biology and Fertility of Soils 31(3):211-218.

Franzluebbers, A.J. 1999. Microbial activity in response to water-filled pore space of variably eroded southern Piedmont soils. Applied Soil Ecology 11(1):91-101.

Gee, G,W., Bauder, J.W. 1986. Particle size analysis. In: Klute, A. (Ed.), methods of soil analysis: part 1.
Physical and Mineralogical Methods, 2nd ed. Agron. Monogr. 9. ASA and SSSA, Madison, WI, USA.

Golombek, S.D., Gebauer, J., and Buerkert, A. 2007. Photosynthetic water-use efficiency of irrigated winter and summer crops in a typical mountain oasis of northern Oman. Journal of Plant Nutrition and Soil Science 170:98-105.

Hedlund, A., Witter, E. and An, B.X. 2003. Assessment of $\mathrm{N}, \mathrm{P}$ and $\mathrm{K}$ management by nutrient balances and flows on peri-urban smallholder farms in southern Vietnam. European Journal of Agronomy 20:71-87.

Jarecki, M.K., Parkin, T.B., Chan, A.S.K., Hatfield, J.L., and Jones, R. 2008. Greenhouse gas emissions from two soils receiving nitrogen fertilizer and swine manure slurry. Journal of Environmental Quality 37(4):1432-1438.

Kelting, D.L., Burger, J.A., and Edwards, G.S. 1998. Estimating root respiration, microbial respiration in the rhizosphere, and root-free soil respiration in forest soils. Soil Biology and Biochemistry 30(7):961-968.

Kimetu, J., Lehmann, J., Ngoze, S., Mugendi, D., Kinyangi, J., Riha, S., Verchot, L., Recha, J., and Pell, A. 2008. Reversibility of soil productivity decline with organic matter of differing quality along a degradation gradient. Ecosystems 11(5):726-739.

Kladivko, E.J., and Keeney, D.R. 1987. Soil nitrogen mineralization as affected by water and temperature interactions. Biology and Fertility of Soils 5(3):248-252.

Klein, M., and Venezian, A. 1985. The Dubas date tropiduchid, Ommatissus binotatus lybicus, a threat to date palms in Israel. Phytoparasitica 13(2):95-101.

Klemmedson, J.O. 1989. Soil organic matter in arid and semiarid ecosystems: Sources, accumulation, and distribution. Arid Soil Research and Rehabilitation 3(2):99-114.

Kuzyakov, Y. 2002. Separating microbial respiration of exudates from root respiration in non-sterile soils: a comparison of four methods. Soil Biology and Biochemistry 34(11):1621-1631.

Kuzyakov, Y. 2006. Sources of $\mathrm{CO}_{2}$ efflux from soil and review of partitioning methods. Soil Biology and Biochemistry 38(3):425-448.

Kuzyakov, Y., and Domanski, G. 2000. Carbon input by plants into the soil. Review. Journal of Plant Nutrition and Soil Science 163:421-431.

Kuzyakov, Y., and Larionova, A.A. 2006. Contribution of rhizomicrobial and root respiration to the $\mathrm{CO}_{2}$ emission from soil (A review). Eurasian Soil Science 39(7):842-854.

Lang, F., and Kaupenjohann, M. 2004. Trace element release from forest floor can be monitored by ion exchange resin tubes. Journal of Plant Nutrition and Soil Science 167:177-183. 
Luedeling, E., Nagieb, M., Wichern, F., Brandt, M., Deurer, M., and Buerkert, A. 2005. Drainage, salt leaching and physico-chemical properties of irrigated manmade terrace soils in a mountain oasis of northern Oman. Geoderma 125 (3-4):273-285.

Mikkelsen, R. 2005. Nutrient use efficiency: using nutrient budgets. Western Nutrient Management Conference 6:2-7.

Mokhtar, A., and Al Nabhani, S. 2010. Temperature-dependent development of dubas bug, Ommatissus lybicus (Hemiptera: Tropiduchidae), an endemic pest of date palm, Phoenix dactylifera. European Journal of Entomology 107:681-685.

Nagieb, M., Häser, J., Siebert, S., Luedeling, E., and Buerkert, A. 2004. Settlement history of a mountain oasis in northern Oman - evidence from land-use and archaeological studies. Die Erde 135 (1):81-106.

Nierop, K.G.J., Pulleman, M.M., Marinissen, J.C.Y. 2001. Management induced organic matter differentiation in grassland and arable soil: a study using pyrolysis techniques. Soil Biology and Biochemistry 33(6):755764.

Nyberg, K., Schnürer, A., Sundh, I., Jarvis, Å., and Hallin S. 2006. Ammonia-oxidizing communities in agricultural soil incubated with organic waste residues. Biology and Fertility of Soils 42(4):315-323.

Ouédraogo, E., Mando, A., and Zombré, N.P. 2001. Use of compost to improve soil properties and crop productivity under low input agricultural system in West Africa. Agriculture, Ecosystems and Environment 84(3):259-266.

Predotova, M., Bischoff, W.-A., and Buerkert, A. 2011. Mineral nitrogen and phosphorus leaching in vegetable gardens of Niamey, Niger. Journal of Plant Nutrition and Soil Science 174:47-55.

Predotova, M., Gebauer, J., Diogo, R.V.C., Schlecht, E. and Buerkert, A. 2010. Gaseous nitrogen and carbon emissions from urban gardens in Niamey, Niger. Field Crops Research 115:1-8.

Predotova, M., Kretschmann, R., Gebauer, J., and Buerkert, A. 2011.. Effects of cuvette surface material on ammonia, nitrous oxide, carbon dioxide and methane concentration measurements. Journal of Soil Science and Plant Nutrition 174, 347-349.

Paré, T., Gregorich, E.G., and Nelson, S. 2000. Mineralization of nitrogen from crop residues and $\mathrm{N}$ recovery by maize inoculated with vesicular-arbuscular mycorrhizal fungi. Plant and Soil 218(1):11-20.

Pumpanen, J., Heinonsalo, J., Rasilo, T., Hurme, K.-R., and Ilvesniemi, H. 2009. Carbon balance and allocation of assimilated $\mathrm{CO}_{2}$ in Scots pine, Norway spruce, and Silver birch seedlings determined with gas exchange measurements and ${ }^{14} \mathrm{C}$ pulse labelling. Trees - Structure and Function 23(3):611-621.
Robinson, C.H. 2002. Controls on decomposition and soil nitrogen availability at high latitudes. Plant and Soil 242(1):65-81.

Safi, Z., Predotova, M., Schlecht, E., and Buerkert, A. 2011. Horizontal matter fluxes and leaching losses in urban and peri-urban agriculture of Kabul, Afghanistan. Journal of Plant Nutrition and Soil Science 174(6):942-951.

Scoones, I., and Toulmin, C. 1998. Soil nutrient balances: what use for policy? Agriculture, Ecosystems and Environment 71:255-267.

Sheldrick, W.F., Syers, J.K., and Lingard, J. 2002. A conceptual model for conducting nutrient audits at national, regional, and global scales. Nutrient Cycling in Agroecosystems 62(1):61-72.

Siebert, S., Nagieb, M., and Buerkert, A. 2007. Climate and irrigation water use of a mountain oasis in northern Oman. Agricultural Water Management 89(12):1-14.

Siegfried, K., Dietz, H., Schlecht, E., and Buerkert, A. 2011. Nutrient and carbon balances in organic vegetable production on an irrigated, sandy soil in northern Oman. Journal of Plant Nutrition and Soil Science 175:1-12.

Szili-Kovács, T., Török, K., and Tilston, E.L. 2007. Promoting microbial immobilization of soil nitrogen during restoration of abandoned agricultural fields by organic additions. Biology and Fertility of Soils 43(6):823-828.

Watanabe, F.S., and Olsen, S.R. 1965. Test of an ascorbic acid method for determining phosphorus in water and $\mathrm{NaHCO}_{3}$ extracts from soils. Soil Science Society of America Proceedings 29:677-678.

Werth, M., and Kuzyakov, Y. 2008. Root-derived carbon in soil respiration and microbial biomass determined by ${ }^{14} \mathrm{C}$ and ${ }^{13} \mathrm{C}$. Soil Biology and Biochemistry 40(3):625-637.

Wichern, F., Luedeling, E., Müller, T., Joergensen, R.G., and Buerkert, A. 2004. Field measurements of the $\mathrm{CO}_{2}$ evolution rate under different crops during an irrigation cycle in a mountain oasis of Oman. Applied Soil Ecology 25:85-91.

Wichern, F., Müller, T., Joergensen, R.G., and Buerkert, A. 2004. Effects of manure quality and application forms on soil $\mathrm{C}$ and $\mathrm{N}$ turnover of a subtropical oasis soil under laboratory conditions. Biology and Fertility of Soils 39(3):165-171.

Williams, D.E. 1948. A rapid manometer method for the determination of carbonate in soils. Soil Science Society of America Journal 13:127-129.

Zaman, M., and Chang, S.X. 2004. Substrate type, temperature, and moisture content affect gross and net $\mathrm{N}$ mineralization and nitrification rates in agroforestry systems. Biology and Fertility of Soils 39(4):269-279. 